\title{
Tradition as a Source of Dance Choreography Creation
}

\author{
Ni Nyoman Seriati*, Trie Wahyuni, Pramularsih Wulansari \\ Faculty of Art and Languages, Yogyakarta State University, Yogyakarta, Indonesia \\ *Corresponding author.Email: ni_nyomanseriati@uny.ac.id
}

\begin{abstract}
This study aimed to make Nusantara (Indonesian) traditional dance-based choreography design which was intended for junior high school students and could be performed by both male and female students. The dance performance could be done solo or in groups. The dance movements were developed from several movements in Javanese, Balinese, and Sumatran dances which were assembled into a single form that emphasizes the agility of junior high school students. This was development research (R\&D) which produced a dance design for junior high school students. The data were collected through a survey with the questionnaire, observation, interview, and documentation. The researchers analyzed the data using a qualitative descriptive technique through the expert and user validation, and content validation for each dance step. The results of this study indicate that the movements are developed through the stages of exploration, improvisation, and forming. They were based on the variety of traditional Javanese dance movements (Yogyakarta and Surakarta) combined with Balinese and Sumatran dance styles. The results of validation by the expert and users of the choreography design that has been tried out in the field show that: for the main movements, $20 \%$ answer 'very easy', 'easy' (45\%), and difficult (35\%). Meanwhile, for the joint motion elements, $60 \%$ state that it was very easy, and 'easy' by $40 \%$. This shows that the choreography design of the Sigrak Kumandang dance can be performed by junior high school students.
\end{abstract}

Keywords: Tradition, Source of creation, Dance choreography

\section{INTRODUCTION}

Dance or dance creation always deals with creativity and develops in individuals who have high motivation in a creative process. The creativity in dance creation can be explored through the existing classical and folk arts. These two types of art that are endlessly explored as references in creating new works such as dance movements, clothing, music, stories, and others become the inspiration for both natural and academic artists. Traditional arts in general describe the social conditions of the art communities.

In Indonesia, both traditional classical and folk arts are still developing well today. For example, classical art develops well in areas where the influence of the Kraton (palace) is strong, such as in Yogyakarta, Surakarta, Cirebon, and other areas. Meanwhile, folk dance thrives in cultural areas throughout Indonesia. With the promotion of tourist destinations, dance is regarded as one of the attractions; thus, many traditional dances have been revived. Sometimes, dance is promoted as a tourism spot attraction in certain areas; this is one of the reasons to create tour packages.
In addition to tour packages, in a few decades, dance art has become a compulsory subject in schools, which is included in the subject of Culture and Arts. The dance art is taught from kindergarten to high school and in intracurricular and extracurricular programs. The material taught is the dances in each region or dances as the cultural identity of certain areas. Most of the learning materials in schools provide the existing dances developed in society, both classical and folk. This condition makes the materials for learning dance monotonous and only becomes the teacher's routine in teaching. The material is mostly dances performed by girls/women; thus, male students do not respect dance learning.

The traditional arts that have developed in each region are plentiful in any formation performed solo, in pairs, in groups, and in mass. Likewise, there are dance movements performed very gently, dynamically, attractively with a strong beat. To make the existing traditional arts survive needs preservation by using traditional arts as an inspiration in producing new 
works appropriate for the conditions of the supporting community.

In connection with the description above, this research produces a dance choreography design by developing the existing traditional movements. This dance design is intended for junior high school students, which can be executed by both male and female students. The dynamic movements are selected

\section{LITERATURE REVIEW}

Designing dance movements originating from trades applies a choreography theory. The technical choreography arrangement is a creativity result by conducting activities to find new movement possibilities from the existing traditional art forms of movements. The processing of new dances that originate from ethnic materials is regarded as 'creative tradition'. The process of creating performing arts, in this case, the art of dance, is based on the three main points, namely will, feel, and creation. Will is the desire or motivation to do something; feel is an intellectual activity; and creation is a construction activity or making dance work [3].

Choreography as a concept in the design of dance works includes the processes of planning, selection, and forming of dance movements with specific aims and objectives [1]. The process of creating dance choreography consists of three stages: exploration, improvisation, and forming. Creativity at the exploration stage is an experience to explore ideas; the development of creativity at the improvisation stage is defined as the spontaneous discovery of movements, and the final stage is the forming of "dance choreography" [2]. The choreography of new dance creations belongs to the framework of traditional dance aesthetics which has been adapted to be dance steps that have undergone reinterpretations or changes. The freedom of creativity in new creations of dance choreography is still within the aesthetic framework of traditional dances which have been processed to become a choreography with reinterpretations or changes [1].

Creativity is a change of the old order to be a new and better one. It is the freedom to contemplate and create new forms and to apply the results to replace the old ones to produce actual creations [6]. Creativity contains two important concepts: creation and novelty [4]. It is developed through explorations on things by modifying them to stimulate creativity.

\section{RESEARCH METHOD}

This study employed a development research ( $R$ \& D) method to produce and test the effectiveness of certain products. In line with its nature to produce a product, a needs analysis is significant [5]. This study developed a product in the form of dance choreography for junior high school students. The choreography for junior high school students because they are in the transition period from children to adolescents; therefore, this dance work adapts to the conditions of the students. Based on the issue, the formulation of the problem is 'How is the design of the traditional artsbased dance choreography? The aim of this study is to design choreography oriented to traditional movements for dance learning in junior high school.

development was carried out by adapting the R \& D model by Sugiyono [5] as follows:

a) Carrying out a preliminary study by identifying the needs of dance teachers in schools

b) Designing choreography through the cultivation stage of the dance, which includes exploration, improvisation, evaluation, and composition

c) Developing a product of the choreography design draft based on the local wisdom (several dances in Indonesia) for dance learning in schools

d) Conducting a limited try-out

e) Conducting validation by the material expert

f) Making revisions

g) Finalizing the choreography design draft for junior high school students

The development steps are illustrated in Figure 1 below.

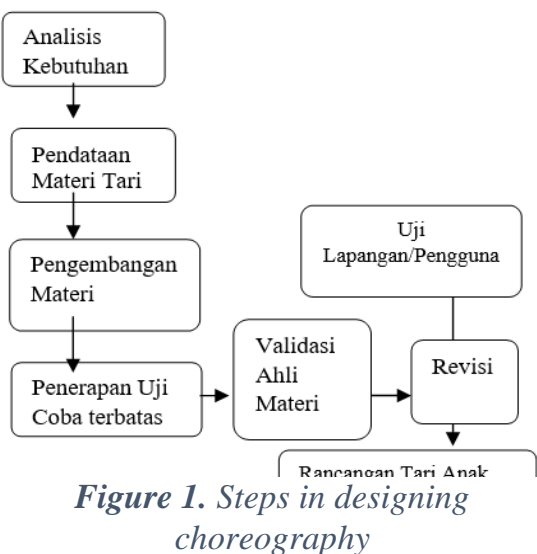

Note:

Needs Analysis

Dance Material Collection

Material Development

Limited Try-Out

Validation by Material Expert

Revision

Field/User Test

a) Needs Analysis

This stage was carried out by observing and identifying the needs of learning materials of 
dance practice in junior high schools. The observations involved culture and arts (dance) teachers to obtain accurate information. The observation results found that schools need creative dances that can be performed by male and female students. So far, the existing materials are mostly dances with female dancers; obviously, they are not possible to be performed by male students. The materials in dance are expected to present the nuances of this archipelago based on the culture and arts curriculum.

\section{b) Collection of Dance Variation}

The step includes the material collection of Indonesian dance variations. In connection with this, it is not possible to record all the Indonesian dances; therefore, three traditional dance styles were selected, namely Javanese (Yogyakarta and Surakarta), Balinese, and Sumatran. The reason for selecting these three regions is to create a more dynamic and appropriate dance for junior high school children who like things with quick and agile movements. Some of the varieties recorded include dance movements of Malay pencaksilat that adopt the jumping, cross-arm movements, and footsteps in the Limpapeh dance, and footsteps in the Malay (Sumatra) dance. It also adopts the basic movements of malpal, miles, and kipekan in the Balinese dance, tumpang tali in the Javanese dance moves (Surakarta), kapang-kapang steps, and trisig transition in Yogyakarta dance.

c) Material Development

Developing a choreographic design product based on the draft making employed dance cultivation stages: exploration, improvisation on Indonesian dances, and forming of dance movements.

d) Draft Try-Out

The draft try-out designed to collect data was used as a basis for following up the dance design to be made. The data obtained in the draft tryout were used to improve the composed choreography design, and to perfect and simplify the dance movements in the dance draft. In the limited try-out, the researchers employed several junior high school students studying dance in the Pradnya Widya Studio, Faculty of Languages and Arts, UNY. Students are expected to provide inputs, feedbacks, and comments on any dance variation provided through practices. The input from the students was analyzed and used as the basis to revise the dance materials. e) Validation by Material Expert

Before the design draft was tested in the field, it was validated by a material expert. The material expert provided input, assessed the composed draft, and corrected the main and transition movements to determine the level of difficulty and complexity. The results obtained from the validation were regarded as references to improve the design draft of dance choreography and to perfect each movement used in the dance composition.

\subsection{Data Collection Technique}

\subsubsection{Data Population, Sample, and Data Source}

The population of this study consisted of 10 junior high school students in the Yogyakarta Special Region and a material expert.

\subsubsection{Data Collection Techniques}

a) A survey with a questionnaire used to collect data on the dance movement designed; it is an open questionnaire completed with columns and additional notes for the validator and users.

b) Documentation, collecting data on dance variation often used in several dances.

\subsubsection{Research Instrument}

The questionnaire was employed as the research instrument given to the material expert, try-out subjects, and field test subjects. This instrument was used to provide an assessment of the acceptability of the dance design, particularly in the series of main and joint movements.

\subsection{Data Analysis Technique}

\subsubsection{Content Analysis}

The qualitative data were obtained from the comments by the material expert, limited try-out subjects, and field test subjects. The results were analyzed using a content analysis technique. In addition to the comments by the material expert, try-out subjects, and field test subjects, the observation data in the form of responses, questions, criticism, and suggestions were grouped as descriptive data used to improve the dance choreography designs.

\subsubsection{Descriptive Statistics Analysis}

The data from the questionnaire distributed to the test subjects and a material expert were analyzed using a rating scale from 1 to 4 . The analysis of data obtained from the validation process in the form of statements was converted into quantitative data with a scale of 4 with the following scoring. 
Table 1. Scoring on the difficulty/ease level

\begin{tabular}{|c|c|c|}
\hline No. & $\begin{array}{c}\text { Score in } \\
\text { Percentage }\end{array}$ & $\begin{array}{c}\text { Acceptance/Appropriateness } \\
\text { Criteria }\end{array}$ \\
\hline 1. & $0-24 \%$ & Very Difficult \\
\hline 2. & $25 \%-49 \%$ & Difficult \\
\hline 3. & $50 \%-74 \%$ & Easy \\
\hline 4. & $75 \%-100 \%$ & Very Easy \\
\hline
\end{tabular}

To calculate the total of maximum scores uses the formula:

Total maximum score $=($ Number of items $\mathrm{x}$ maximum score) $\mathrm{N}$

To find the percentage score uses the formula:

Total of the obtained score

Total score

\section{100}

The qualitative and quantitative data analysis serves as the basis for revising the choreography design. The qualitative data include suggestions, comments, criticisms, and input for the design.

\section{RESEARCH FINDINGS AND DISCUSSION}

\subsection{Procedure in Designing Traditional Dance-Based Choreography}

\subsubsection{Needs Analysis}

This stage was conducted through a field study and the data obtained show that the dance material provided was mostly about the existing dances. Most of the materials are more appropriate for female students; thus, they are less accommodating the male students. Therefore, it is necessary to design a dance that can be performed by both female and male students with a movement basis in traditional Indonesian dances. This design aims to motivate the dance teachers in junior high schools to create dance works for learning purposes. This activity can also be implemented as a strategy for developing student creativity. For the limited try-out, ten junior high school students were selected from several schools in Yogyakarta Special Region.

\subsubsection{Material Collection}

The material collection on the variaton of traditional dances used in the design includes the movement variations of kapang-kapang, jomplangan, tranjalan, sembahan jengkeng, and the tumpang tali hand position taken from Yogyakarta and Surakarta dances. Meanwhile, to give a strong and firm impression, the malpal footstep in the Baris dance, the miles and kipekan movements, and agem attitude in traditional Balinese dance are included. Furthermore, the researchers adopted silat, clapping, jumping, and dable steps from the Limpapeh dance in West Sumatra. The above activities were carried out in exploration activities, i.e., collecting dance movement variations assumed to represent the behavior of junior high school students.

\subsubsection{Material Development}

This is the creation process using three stages of choreography: exploration, improvisation, and forming. The exploration activities were carried out by collecting the dance movements from the four regions mentioned above. The next activity was studio work (improvisation) on the collected movements to be developed and adapted to the dance theme, i.e., the joy and dexterity of youngsters in studying at schools. The choreography structure of the dance includes 1) opening, 2) development, 3) climax, and 4) choreography design with the name of Sigrak Kumandang dance.

\subsection{Validation Results}

\subsubsection{Results of the Limited Validation and Revision}

The try-out of the composed movement series was carried out through limited validation with 10 students in Grades 7 and 8 . This activity aimed to identify the level of difficulty of each movement variation. The activity began by explaining the background, theme, and dance title.

Furthermore, the model demonstrated each dance movement variation followed by the students. During the demonstration of each movement, students were given chances to ask questions about the difficulties and unclear variations of movement.

The limited test subjects contributed their full concentration to participate in the activities to create an easy and smooth process, especially in providing materials for the main and joint/transition movements. Thus, the entire series of movements can be performed effectively and efficiently. This activity, 
simultaneously, develops students' creativity to be able to imitate the movements quickly and precisely.

Feedback from the participants is significant for the improvement of the materials. After the training activities, they were asked to fill out a questionnaire. Based on the students' answers to the elements of the main movement variations, $20 \%$ of the students answer 'very easy', 'easy' by $45 \%$, and 'difficult' by $35 \%$. Meanwhile, regarding the joint movement element, $60 \%$ state it is very easy, and $40 \%$ say 'easy'. The results of the evaluation by the participants function as references to revise the main movements said to be difficult. Those difficult dance movements lie in making the steps and lifting the legs with a fast tempo.

The improvements were made by simplifying the footsteps and slowing the tempo. Thus, when this material is given at school, it is hoped that all students with and without basic knowledge of dance can perform the choreography well.

\subsubsection{Validation by Material Expert and Revision}

To collect input on the material development of the dance movements and motifs and to identify the shortcomings, a material validation was conducted by an expert (Ni Luh Putu Wiardani, M.Pd.) by presenting the movements in detail on each dance step motif and discussing per part of variation. The validation by the material expert is a basis for developing the dance movement. Based on the first and second stage of validation, the movements with a faster tempo were replaced with the slower ones. In addition, the material expert provided suggestions for making transition movements on the spot at each change of movement to make it easier for students to memorize the dance steps.

\subsubsection{A Follow-Up Study}

The result of the choreography design based on the traditional dances was followed up with a user test at school and the design of the dance costume. The costume was designed based on the dance performance and tried out. The aim was to provide the students with the appropriate dance costume model to perform without difficulties, either in wearing it or in executing the movement.

\section{CONCLUSIONS}

The choreography design based on the traditional arts is entitled Sigrak Kumandang, an expression of dexterity/skill/agility in gaining knowledge at school. This study employed the R\&D development method to produce a dance choreography design through several stages: needs analysis, material collection, material development, limited testing/try-out, material validation, revision, field testing, and choreography design. The choreography design is expected to be useful for adding and enriching creative dance materials for learning in junior high schools. Teachers who learn it are motivated to create new dance creations based on the traditional Indonesian dances. Also, through this choreography design, the teacher can independently apply it as the learning materials to develop students' creativity.

\section{REFERENCES}

[1] Hadi, Y. S. Aspek-aspek dasar koreografi kelompok [Basic aspects of group choreography]. Elkaphi, 2003.

[2] Sumandiyo, H. Koreografi: Bentuk-Teknik-Isi [Choreography: Form-Technique-Content]. Cipta Media, 2011.

[3] Hidayat, Robby. Kreativitas Koreografi, Pengetahuan dan Pratikum Koreografi Bagi Guru [Choreography Creativity, Knowledge and Choreography Practicum for Teachers], Surya Pena Gemilang, 2013.

[4] Junaedi, D. Estetika: Jalinan Subjek, Objek, dan Nilai [Aesthetics: The Weave of Subjects, Objects, and Values], ArtCiv, 2016.

[5] Sugiyono. Metode Penelitian Pendidikan (Pendekatan Kuantitatif, Kualitatif, dan $R \& D$ ) [Educational Research Methods (Quantitative, Qualitative, and R \& D Approaches)]. Alfabeta 2011.

[6] Sachari, Agus. Estetika, Makna, Symbol dan Daya [Aesthetics, Meaning, Symbol and Power]. Institut Teknologi Bandung, 2002. 